\title{
Peningkatan Produktivitas Kerja Melalui Hubungan Kepemimpinan dan Disiplin Kerja Karyawan PT. Pelindo IV (Persero) Makassar
}

\author{
${ }^{1}$ Muhammad Irwan Nur Hamiddin, ${ }^{2}$ Yulian Rinawaty Taaha \\ ${ }^{1}$ Sekolah Tinggi Ilmu Ekonomi Makassar Bongaya, Sulawesi Selatan, Indonesia \\ ${ }^{2}$ Universitas Kristen Tentena, Sulawesi Tengah, Indonesia \\ Email : ${ }^{2}$ irwan.hamiddin@ stiem-bongaya.ac.id, ${ }^{2} y$ uliantaaha07@gmail.com
}

(Diterima: April 2021; Direvisi: April 2021; Dipublikasikan: Mei 2021)

\begin{abstract}
ABSTRAK
Penelitian ini bertujuan untuk menganalisis: (1) pengaruh kepemimpinan terhadap produktivitas kerja, (2) pengaruh disiplin kerja terhadap produktivitas kerja, (3) pengaruh kepemimpinan dan disiplin kerja secara simultan terhadap produktivitas kerja PT. Pelindo IV (persero) Makassar. Penelitian ini merupakan penelitian asosiatif kausal dengan menggunakan pendekatan kuantitatif. Populasi penelitian ini adalah seluruh karyawan tetap PT. Pelindo IV (persero) Makassar. sebanyak 162 karyawan dengan sampel sebanyak 64 responden. Pengumpulan data menggunakan kuesioner dan wawancara, sedangkan analisis data dilakukan dengan menggunakan analisis regresi linier berganda. Hasil penelitian pada taraf signifikansi 5\% menunjukkan bahwa: 1) kepemimpinan berpengaruh positif signifikan terhadap produktivitas kerja, yang ditunjukkan dengan koefisien beta $(\beta)$ 0,677, signifikansi 0,000. 2) disiplin kerja berpengaruh positif dan tidak signifikan terhadap produktivitas kerja, hal ini ditunjukkan dengan hasil koefisen beta $(\beta)$ 0,105, nilai signifikansi 0,379. 3) kepemimpinan dan disiplin kerja berpengaruh positif dan signifikan terhadap produktivitas kerja.
\end{abstract}

Kata Kunci : Kepemimpinan, Disiplin Kerja, Produktivitas Kerja 


\section{PENDAHULUAN}

PT. Pelindo IV (Persero) Makassar sebuah perusahaan Negara yang bergerak dibidang jasa kepelabuhanan yang beroperasi di Indonesia Bagian Timur. PT. Pelindo IV (Persero) Makassar didirikan berdasarkan Peraturan Pemerintah No. 59 tahun 1991, tentang pengalihan bentuk perseroan umum (perum) Pelabuhan IV menjadi perseroan terbatas (persero) yang mana menyediakan jasa kepelabuhanan dan nonkepelabuhanan (penunjang) seperti jasa kapal, barang, penumpang, terminal petikemas, dan alat lainnya. Kehadiran PT. Pelindo IV (Persero) Makassar sangat mendorong perekonomian wilayah bagian Indonesia bagian timur salah satunya adalah aktivitas layanan logistic antar kota ke kota dan propinsi bias secara cepat tersalurkan.

PT. Pelindo IV (Persero) Makassar memiliki tujuan yang ingin dicapai, dalam usaha pencapaian tujuan, perusahaan sangat berperan penting dalam mengelola, mengatur, dan menggunakan sumber daya manusia agar perusahaan dapat bekerja secara produktif, efektif dan efisien. Setiap perusahaan punya latar belakang yang berbeda dan permasalahan yang berbeda pula, tidak dapat dipungkiri bahwa permasalahan yang sering muncul pada perusahaan adalah masalah pada sumber daya manusia, karena itu setiap perusahaan harus selalu memerhatikan sumber daya manusianya agar dapat bekerja sama dalam suatu perusahaan.

Peranan sumber daya manusia memiliki peranan yang sangat strategis dalam menyelenggarakan dan menjalankan bisnis dalam suatu organisasi. peran pegawai sangat penting karena unsur manusia memegang peranan penting dalam melakukan aktivitas kegiatan organisasi dan berperan aktif dalam kebijakan dan pencapaian tujuan organisasi. Dengan sumber daya manusia yang handal maka kegiatan operasional organisasi akan berjalan dengan lancar. Peranan sumber daya manusia sangat penting dalam suatu organisasi, baik organisasi swasta maupun organisasi pemerintah atau Badan Usaha Milik Negara (BUMN).

Perusahaan harus selalu bisa mengarahkan seluruh karyawan dan memahamkan tujuan dari perusahaan tersebut. Tujuan tidak mungkin terwujud tanpa peran aktif karyawan meskipun alat-alat yang dimiliki perusahaan begitu canggihnya (Hasibuan, 2012). Perusahaan yang mampu mengelola sekaligus mengembangkan sumber daya manusia yang dimiliki, akan menghasilkan karyawan yang mempunyai kinerja yang baik, karena kelangsungan suatu perusahaan sangat ditentukan oleh kinerja karyawan. Dalam usaha menghasilkan kinerja karyawan yang baik perusahaan perlu melakukan penilaian kinerja guna menganalisis dan mengetahui perkembangan dan kontribusi dari seluruh karyawan.

Menurut Hasibuan (2012) dikatakannya bahwa Manusia merupakan unsur penting, karena unsur-unsur lainnya yang dimiliki organisasi seperti uang, materi mesinmesin, metode kerja, waktu dan kekayaan lainnya hanya dapat bermanfaat bagi organisasi, jika manusia yang ada dalam organisasi itu dimanfaatkan secara maksimal. 
Gaya Kepemimpinan (Luthans, 2011) dalam Jumady (2020) merupakan cara pimpinan untuk mempengaruhi orang lain atau bawahannya sedemikian rupa sehingga mau melakukan kehendak pimpinan untuk mencapai tujuan organisasi meskipun secara pribadi hal tersebut mungkin tidak disenangi. Sejumlah peneliti berteori bahwa kepemimpinan terkait dengan kinerja dan produktivitas (Huang, 2010). Masing-masing gaya kepemimpinan ini telah mendapat perhatian penting dalam literatur manajemen dan dalam dunia bisnis. Sedangkan hasil penelitian Xenikou (2006) bahwa kepemimpinan transformasional memiliki dampak positif tidak langsung pada kinerja melalui orientasi pencapaian.

Widodo (2010) menyatakan bahwa kepemimpinan berpengaruh positif signifikan terhadap produktivitas karyawan kecamatan Sidorejo Kota salatiga. Temuan ini dibantahkan oleh (Posuma, 2013) bahwa kepemimpinan tidak berpengaruh terhadap produktivitas karyawan pada Rumah Sakit Ratumbuysang Manado.

Selain gaya kepemimpinan, kedisiplinan merupakan salah satu cara agar dapat menciptakan produktivitas karyawan yang baik. Perusahaan yang dapat menciptakan budaya disiplin maka para karyawan akan ikut disiplin dan begitu pula sebaliknya, untuk menghindari atau meminimalisisr terjadinya kesalahan yang dilakukan oleh para karyawan sudah semestinya perusahaan menanamkan kedisiplinan untuk para karyawan agar selalu mengikuti peraturan dan tata tertib yang telah dibuat oleh perusahaan tersebut.
Menurut Hasibuan (2012) kedisiplinan harus ditegakkan dalam suatu organisasi atau perusahaan. Tanpa dukungan disiplin karyawan yang baik, sulit bagi perusahaan untuk mewujudkan tujuannya.

Prawatya \& Raharjo (2012) bahwa disiplin kerja berpengaruh positif signifikan terhadap kinerja karyawan pada Pabrik Minyak Kayu Putih (PMKP) di Krai Porwodadi. Temuan ini dibantah oleh (Susanty \& Baskoro, 2016) bahwa disiplin kerja tidak berpengaruh terhadap kinerja pegawai

Berdasarkan latar belakang permasalahan diatas, maka penulis tertarik untuk melakukan penelitian lebih lanjut dengan judul: "Peningkatan Produktivitas Kerja Melalui Hubungan Kepemimpinan dan Disiplin Kerja Karyawan PT. Pelindo IV (Persero) Makassar".

\section{TINJAUAN PUSTAKA}

\section{Kepemimpinan}

Menurut Robbins (1996) dalam Jannah (2020) menyatakan bahwa kepemimpinan merupakan kemampuan untuk mempengaruhi suatu kelompok kearah tercapainya suatu tujuan. Kepemimpinan adalah pengaruh antara pribadi yang dijalankan dalam situasi tertentu, serta diarahkan melalui proses komunikasi ke arah pencapaian satu atau beberapa tujuan tertentu.

Mangkuprawira dan Hubeis (2007) Kepemimpinan adalah gaya dan perilaku seseorang untuk membuat orang lain pengikuti apa yang dikehendakinya. Adapun indikator yang digunakan meliputi: 1) Berorientasi pada prestasi, 2) Pandai dalam 
mengarahkan bawahan, 3) Mampu memberikan ide, 4) Berpartisipasi dengan anggota.

\section{Disiplin Kerja}

Menurut Mangkunegara (2013) disiplin kerja diartikan sebagai pelaksanaan manajemen untuk memperteguh pedomanpedoman organisasi. Kadangkadang, perilaku pekerja dalam organisasi menjadi sangat mengganggu sehingga berdampak dengan kinerja yang menurun. Disiplin kerja yang baik dan berkualitas merupakan kunci utama keberhasilan suatu organisasi/instansi dimana apabila hal tersebut diterapkan dengan baik dan benar maka keinginan dan tujuan suatu organiasi/instansi dapat terwujud (Shelviana, 2015).

Slamet, dalam Prawatya dkk (2012) disiplin kerja adalah suatu proses yang dapat menumbuhkan perasaan seseorang untuk mempertahankan / meningkatkan tujuan organisasi secara obyektif, melalui kepatuhan menjalankan peraturan organisasi. Adapun indikator yang digunakan dalam penelitian ini meliputi: 1) tingkat kehadiran, 2) kepatuhan, 3) pelaksanaan tugas, 4) sanksi.

\section{Produktivitas Kerja}

Produktivitas adalah suatu hasil yang dicapai oleh seseorang dalam bidang pekerjaanya menurut kriteria tertentu yang berlaku untuk suatu pekerjaan tertentu dan dievaluasi oleh orangorang. Produktivitas kerja menurut Siagian dalam Niam (2018) adalah kemampuan menghasilkan barang/jasa dari berbagai sumber daya dan kemampuan yang dimiliki oleh setiap pekerja/karyawan.

Demikian pula menurut Serdamayanti dalam Jumady (2020) bahwa produktivitas kerja karyawan adalah hasil kerja secara kualitas dan kuantitas yang dicapai oleh seorang karyawan dalam melaksanakan tugasnya sesuai dengan tanggung jawab yang diberikan kepadanya. Adapun indikator yang digunakan meliputi: 1) kualitas, 2) kuantitas, 3) kreativitas kerja, 4) pengetahuan pekerjaan.

\section{METODE PENELITIAN}

\section{Populasi}

Populasi adalah wilayah generalisasi yang terdiri atas obyek dan subyek yang mempunyai kualitas dan karakteristik tertentu yang ditetapkan oleh peneliti untuk dipelajari dan kemudian ditarik kesimpulannya (Sugiyono, 2013, dalam Gantini, 2014). Populasi dalam penelitian adalah seluruh karyawan yang bekerja pada perusahaan PT. Pelindo IV Makassar yang berjumlah 162 orang Karyawan.

\section{Sampel}

Menurut Sugiyono (2016) yaitu "Sampel adalah jumlah dan karakteristik yang dimiliki oleh populasi tersebut". Sedangkan Suharsini Arikunto (2010) berpendapat bahwa "Sampel adalah sebagian atau wakil populasi yang diteliti". Teknik pengambilan sampel dalam penelitian ini menggunakan rumus Slovin yaitu:

$$
\begin{aligned}
n & =\frac{162}{1+162(0.1)^{2}} \\
& =64 \text { sampel }
\end{aligned}
$$


Sehingga jumlah sampel dalam penelitian ini sebanyak 64 responden.

Tabel 1. Sampel Penelitian

\begin{tabular}{|c|c|c|c|c|}
\hline No & Bagian & $\begin{array}{c}\text { Jumlah } \\
\text { karyawan }\end{array}$ & Strata & $\begin{array}{l}\text { Jumlah } \\
\text { Sampel }\end{array}$ \\
\hline 1 & $\begin{array}{l}\text { Bagian SDM } \\
\text { \& Umum }\end{array}$ & 31 & $19,13 \%$ & 12 \\
\hline 2 & $\begin{array}{l}\text { Bagian } \\
\text { Keuangan }\end{array}$ & 19 & $11,72 \%$ & 8 \\
\hline 3 & $\begin{array}{l}\text { Bagian } \\
\text { Teknik }\end{array}$ & 34 & $21,00 \%$ & 13 \\
\hline 4 & $\begin{array}{l}\text { Bagian } \\
\text { Pelayanan } \\
\text { Barang \& } \\
\text { usaha }\end{array}$ & 26 & $16,05 \%$ & 10 \\
\hline 5 & $\begin{array}{l}\text { Bagian } \\
\text { Pelayanan } \\
\text { Kapal }\end{array}$ & 52 & $32,10 \%$ & 21 \\
\hline & Jumlah & 162 & $100 \%$ & 64 \\
\hline
\end{tabular}

\section{Metode Analisis Data}

Dalam menganalisis data digunakan uji instrumen, uji asumsi klasik, regresi linear berganda, koefisien determinasi dan uji hipotesis.

\section{HASIL PENELITIAN}

\section{Uji Intrumen}

Uji validitas digunakan untuk mengukur valid atau tidaknya suatu kuesioner. Kuesioner akan dikatakan valid apabila pertanyaan yang terdapat pada kuesioner mampu mengungkapkan secara jelas sesuatu yang diukur oleh kuesioner tersebut. Pengujian validitas dilakukan dengan dengan cara mengkorelasi setiap skor variable jawaban responden dengan total skor masing-masing variabel, kemudian hasil korelasi dibandingkan dengan nilai kritis pada taraf siginifikan 0,05 atau 0,01. Menurut Sugiyono (2016) "Valid berarti terdapat kesamaan antara data yang terkumpul dengan data yang sesungguhnya".

Uji berikutnya adalah uni reliabilitas. Uji reliabilitas digunakan untuk menguji sejauh mana pengukuran dari suatu uji coba yang dilakukan tetap memiliki hasil yang sama meskipun dilakukan secara berulang-ulang terhadap subjek dan dalam kondisi yang sama. Instrumen pengukuran dikatakan reliabel apabila memberikan hasil yang konsisten untuk pengukuran yang sama. Uji reliabilitas dalam penelitian ini menggunakan koefisien Cronbach Alpha (a). Apabila nilai a lebih besar dari 0,70 dapat disimpulkan bahwa instrumen yang digunakan dalam penelitian reliabel (Ghozali, 2011). Adapun hasil pengujiannya sebagai berikut:

Tabel 2. Hasil Pengujian Reliabilitas

\begin{tabular}{|l|c|c|c|}
\hline \multicolumn{1}{|c|}{ Variabel } & Cronbach's Alpha & $\begin{array}{c}\text { Standar Kritis } \\
\text { Alpha }\end{array}$ & Keterangan \\
\hline Kepemimpinan (X1) & 0,841 & 0,700 & Reliabel \\
\hline Disiplin kerja (X2) & 0,782 & 0,700 & Reliabel \\
\hline Produktivitas kerja (Y) & 0,806 & 0,700 & Reliabel \\
\hline
\end{tabular}

Berdasarkan hasil pengujuan di atas, Keseluruhan variabel kepemimpinan (X1), disiplin kerja (X2) diperoleh nilai cronbach alpha lebih besar dari 0,70 .
Dengan demikian dinyatakan reliabel.

\section{Uji Asumsi Klasik}

Uji asumsi klasik dimaksudkan untuk mengetahui ketepatan sebuah data. Menurut 
Singgih Santoso (2011) "Sebuah model regresi akan digunakan untuk melakukan peramalan, sebuah model yang baik adalah model dengan kesalahan. Dalam penelitian ini uji asumsi klasik yang digunakan adalah meliputi: Uji Normalitas dan Uji Multikolinearitas. Adapun hasilnya sebagai berikut:

\section{a. Uji Normalitas}

Uji normalitas dilakukan untuk menguji apakah dalam model regresi, variabel dependen dan variabel independen berdistribusi normal atau berdistribusi tidak normal. Hasil uji normalitas dengan alat uji KolmogorovSmirnov Test, sebagai berikut:

Tabel 3. Hasil Normalitas Kolmogorov-Smirnov

Tests of Normality

Kolmogorov-Smirnov ${ }^{\mathrm{a}}$

\begin{tabular}{r|r|r|r|r|r} 
Statistic & \multicolumn{1}{c|}{ df } & \multicolumn{1}{c|}{ Sig. } & \multicolumn{1}{c|}{ Statistic } & df & \multicolumn{1}{c}{ Sig. } \\
\hline .076 & 64 & .200 & .988 & 70 & .791 \\
\hline
\end{tabular}

Produktivitas Kerja (Y) $\quad .076$

a. Lilliefors Significance Correction

Berdasarkan hasil pengujian pada tabel diatas diperoleh nilai signifikansi 0,099 dimana nilai tersebut lebih besar dari nilai $\alpha=0,050$ atau $(0,099>0,050)$. Dengan demikian maka asumsi distribusi persamaan pada uji ini adalah normal.

\section{b. Uji Multikonilieritas}

Untuk mendeteksin ada tidaknya gejala multikolonieritas antar variabel independen digunakan Variance Inflation Factor (VIF) dan Tolerance. Batas dari tolerance Value $>0,10$ dan nilai VIF $<10$ maka tidak terjadi multikolonieritas. Adapun hasil pengujiannya sebagai berikut:

Tabel 4. Hasil Uji Multikolinieritas dengan Collinierity Statistic

\begin{tabular}{|c|c|c|c|c|c|c|}
\hline \multirow{3}{*}{\multicolumn{2}{|c|}{ Model }} & \multicolumn{2}{|c|}{ Coefficients $^{\mathrm{a}}$} & \multirow{3}{*}{$\begin{array}{c}\text { Standardized } \\
\text { Coefficients } \\
\text { Beta } \\
\end{array}$} & \multirow{2}{*}{\multicolumn{2}{|c|}{$\begin{array}{l}\text { Collinearity } \\
\text { Statistics }\end{array}$}} \\
\hline & & \multicolumn{2}{|c|}{$\begin{array}{l}\text { Unstandardized } \\
\text { Coefficients }\end{array}$} & & & \\
\hline & & $\mathrm{B}$ & Std. Error & & Tolerance & VIF \\
\hline \multirow[t]{3}{*}{1} & (Constant) & .828 & .375 & & & \\
\hline & Kepemimpinan (X1) & .685 & .120 & 677 & .506 & 1.975 \\
\hline & Disiplin kerja (X2) & .094 & .107 & .105 & .506 & 1.975 \\
\hline
\end{tabular}

a. Dependent Variable: Produktivitas kerja (Y)

Berdasarkan hasil pengujian tabel 4 diketahui bahwa variabel kepemimpinan dan disiplin kerja memiliki nilai tolerance sebesar $0,971>$ dari 0,10 dan nilai VIF sebesar $1,030<10,00$. Sehingga dapat disimpulkan bahwa tidak terjadi gejala multikolonieritas antara kedua variabel independen.

\section{Analisis Regresi Linear}

Pada analisis ini dimaksudkan untuk mengetahui hubungan variabel independen terhadap variabel dependen. Hubungan variabel kepemimpinan dan disiplin kerja terhadap 
produktivitas kerja pada PT. Pelindo IV (persero) Makassar dapat dilihat dari hasil pengujian regresi pada tabel dibawah ini:

Tabel 5. Hasil Pengujian Regresi Linier Berganda

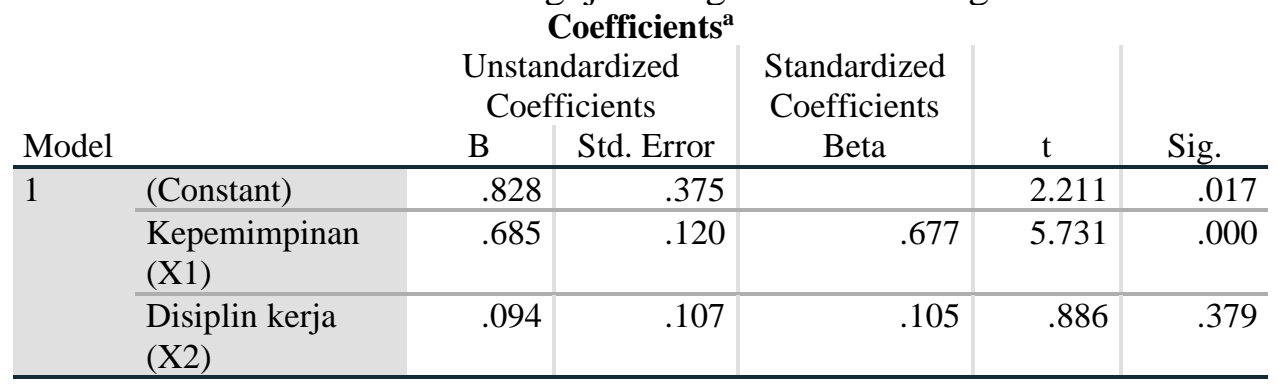

Untuk

sejauhmana

kepemimpinan

mengetahui pengaruh gaya komitmen (X2) terhadap kinerja karyawan (Y) dapat digunakan analisis secara parsial yang dijelaskan melalui persamaan regresi yang diperoleh: $\mathrm{Y}=0,828$ $+0,685 X 1+0,094 X 2$. Persamaan ini dapat dijelaskan sebagai berikut:

1) Konstanta sebesar 0,828 diartikan jika kepemimpinan dan disiplin tidak ada, maka telah terdapat nilai produktivitas sebesar 0,828 point.

Tabel 6. Hasil Pengujian Koefisien Determinasi Kepemimpinan dan Disiplin Kerja secara simultan Terhadap Produktivitas Kerja

\section{Model Summary}

\begin{tabular}{lr|r|r|rr} 
Model & & \multicolumn{2}{c}{$\begin{array}{c}\text { Adjusted R } \\
\text { Square }\end{array}$} & \multicolumn{2}{c}{$\begin{array}{c}\text { Std. Error of the } \\
\text { Estimate }\end{array}$} \\
\hline 1 & $\mathrm{R}$ & R Square & \multicolumn{1}{c|}{ Square } \\
\hline
\end{tabular}

a. Predictors: (Constant), Disiplin kerja (X2), Kepemimpinan (X1)

Berdasarkan tabel 6 diatas menunjukkan bahwa nilai R Square 0,569 atau $56,9 \%$ mempunyai arti bahwa nilai $\mathrm{R}$ Square cukup tinggi, dengan kata lain variabel kepemimpinan dan disiplin kerja mampu menjelaskan variabel produktivitas kerja dengan nilai sebesar $56,9 \%$ sedangkan sisanya $43,1 \%$ dijelaskan oleh variabel lain yang tidak diikutkan dalam penelitian ini.

\section{a. Uji Hipotesis Parsial (Uji t)}

Uji $t$ dilakukan untuk mengetahui hubungan antara masing-masing variabel independen terhadap variabel dependen. Kriteria pengujian 
yang digunakan dengan membandingkan nilai signifikan yang diperoleh dengan taraf signifikan yang diperoleh dengan taraf signifikan yang telah ditentukan yaitu 0,05. Apabila nilai signifikan yang diperoleh $<0,05$ maka individu variabel independent mempengaruhi variabel dependen secara signifikan. Sedangkan apabila nilai signifikan >0,05 maka variabel independent secara individu tidak mempengaruhi variable dependen secara signifikan. Selain itu juga dengan membandingkan thitung dengan ttabel dengan kriteria sebagai berikut.

Hipotesis pertama: Kepemimpinan berpengaruh positif dan signifikan terhadap produktivitas kerja.

Tabel 7. Hasil Uji Hipotesis Kepemimpinan dan Disiplin kerja Terhadap

\begin{tabular}{|c|c|c|c|c|c|c|}
\hline \multirow[b]{3}{*}{ Model } & & \multicolumn{3}{|c|}{$\begin{array}{c}\text { Produktivitas kerja } \\
\text { Coefficients }^{\mathbf{a}}\end{array}$} & \multirow[b]{3}{*}{$\mathrm{t}$} & \multirow[b]{3}{*}{ Sig. } \\
\hline & & \multicolumn{2}{|c|}{$\begin{array}{l}\text { Unstandardized } \\
\text { Coefficients }\end{array}$} & \multirow{2}{*}{$\begin{array}{c}\text { Standardized } \\
\text { Coefficients } \\
\text { Beta } \\
\end{array}$} & & \\
\hline & & $\mathrm{B}$ & Std. Error & & & \\
\hline \multirow[t]{3}{*}{1} & (Constant) & .828 & .375 & & 2.211 & .017 \\
\hline & $\begin{array}{l}\text { Kepemimpinan } \\
\text { (X1) }\end{array}$ & .685 & .120 & .677 & 5.731 & .000 \\
\hline & $\begin{array}{l}\text { Disiplin kerja } \\
\text { (X2) }\end{array}$ & .094 & .107 & .105 & .886 & .379 \\
\hline
\end{tabular}

Berdasarkan hasil pengujian pada tabel 7 , diperoleh nilai sig $<0,05$ $(0,000)$, dengan demikian hipotesis pertama yang diajukan bahwa terdapat pengaruh yang signifikan atara kepemimpinan terhadap produktivitas kerja diterima.

Hipotesis kedua: disiplin kerja berpengaruh positif dan signifikan terhadap produktivitas kerja.

Berdasarkan hasil pengujian pada tabel 7 , diperoleh nilai sig $>0,05$
$(0,379)$, dengan demikian hipotesis kedua yang diajukan bahwa terdapat pengaruh yang signifikan atara kepemimpinan terhadap produktivitas kerja ditolak.

\section{b. Uji Hipotesis Simultan (Uji F)}

Pengujian hipotesis dengan uji $\mathrm{F}$ digunakan untuk mengetahui hipotesis simultan yang mana yang diterima.

Hipotesis ketiga Terdapat pengaruh yang signifikan antara pengembangan karir dan pelatihan kerja terhadap kinerja pegawai.

Tabel 8. Hasil Uji Simultan Kepemimpinan dan Disiplin kerja Terhadap

Produktivitas kerja

\section{ANOVA}

\begin{tabular}{llr|r|r|r|r} 
Model & & Sum of Squares & df & Mean Square & F & \multicolumn{1}{c}{ Sig. } \\
\hline \multirow{2}{*}{1} & Regression & 10.092 & 2 & 5.046 & 40.242 & $.000^{\mathrm{b}}$ \\
\cline { 2 - 7 } & Residual & 7.649 & 61 & .125 & & \\
\cline { 2 - 7 } & Total & 17.741 & 63 & & & \\
\hline
\end{tabular}


Berdasarkan tabel 8 dapat dilihat bahwa besarnya $F_{\text {hitung }}$ sebesar 40,242 dan signifikan pada tingkat kepercayaan 5\% $(\alpha=0,05)$, nilai signifikan yang diperoleh sebesar 0,000 lebih kecil dari 0,05. Nilai $F_{\text {tabel }}$ dengan $\alpha=0,05$ dan derajat bebas $=64-2-1=61$ maka diperoleh $\mathrm{F}_{\text {tabel }}$ sebesar 3,172.

Oleh karena itu $F_{\text {hitung }}$ 40,242 lebih besar dibandingkan $\mathrm{F}_{\text {tabel }} \quad 3,172$ maka dengan derajat kekeliruan $5 \% \quad(\alpha=0,05) \quad$ dan tingkat signifikannya 0,000 lebih kecil dari 0,05 jadi, $\mathrm{H}_{\mathrm{a}}$ diterima dan $\mathrm{H}_{0}$ ditolak. Artinya dapat dikatakan bahwa kepemimpinan dan disiplin kerja secara simultan berpengaruh signifikan terhadap produktivitas kerja.

\section{PEMBAHASAN}

HASIL

\section{PENELITIAN}

\section{Pengaruh \\ Kepemimpinan \\ Terhadap Produktivitas Kerja}

Dari hasil pengujian hipotesis terbukti bahwa kepemimpinan terhadap produktivitas kerja PT. Pelindo IV (persero) Makassar berpengaruh positif dan signifikan.

Dalam penelitian ini dapat dilihat dari nilai koefisien beta $(\beta)$ sebesar 0,677 dan sig $<0,05$ $(0,000)$ yang menunjukkan bahwa kepemimpinan pada PT. Pelindo IV (persero) Makassar mampu mengayomi bawahan namun terbukti nyata mampu meningkat produktivitas karyawan, kondisi tersebut diakibatkan karena pelaksanaan tugas yang diberikan manager kepada bawahan dapat selesaikan dengan baik sehingga berdampak pada tingginya produktivitas pekerjaan yang diselesaikan.

Hasil penelitian ini sejalan dengan Suryani (2020) ini menunjukkan bahwa terdapat pengaruh yang signifikan baik secara parsial maupun simultan antara variabel motivasi dan gaya kepemimpinan terhadap produktivitas kerja di PT Tuntex Garment Indonesia Cikupa 1 Kecamatan Cikupa Kabupaten Tangerang. Kemudian penelitian Asbari M (2020) kepemimpinan transformasional memberikan efek positif dan signifikan terhadap iklim organisasi dan juga disimpulkan bahwa pada variabel Kepemimpinan transformasional dan iklim organisasi juga memberikan efek positif dan signifikan terhadap Produktivitas kerja inovatif secara parsial dan simultan.

Hasil ini dibantah temuan dalam penelitian sebelumnya oleh (Jumady, 2020; Posuma, 2013; D. S. Widodo, 2014) memberikan bukti bahwa kepemimpinan berpengaruh negative dan tidak signifikan terhadap produktivitas karyawan.

\section{Pengaruh Disiplin Kerja} Terhadap Kinerja Pegawai

Dari hasil pengujian hipotesis ditolak bahwa disiplin kerja terhadap produktivitas kerja PT. Pelindo IV (persero) Makassar berpengaruh positif dan tidak signifikan. Dalam penelitian ini dapat dilihat dari nilai koefisien beta $(\beta)$ sebesar 0,105 dan sig > $0,05(0,379)$ yang menunjukkan bahwa disiplin kerja pada PT. 
Pelindo IV (persero) Makassar masih dibawah standar yang telah ditetapkan.

Hasil penelitian ini sejalan dengan penelitian yang telah dilakukan oleh Siswadi (2017) dimana hasil penelitian variabel disiplin kerja berpengaruh terhadap produktivitas kerja karyawan diperoleh nilai 4,154>1,997 dengan taraf signifikan $0,000<0,05$ objek penelitian PT. Jasa Marga Cabang Medang

3. Pengaruh Kepemimpinan dan Disiplin Kerja Terhadap Produktivitas Kerja

Dari hasil pengujian hipotesis bahwa secara simultan kepemimpinan dan disiplin kerja terhadap produktivitas kerja PT. Pelindo IV (persero) Makassar berpengaruh positif dan signifikan. Dalam penelitian ini dapat dilihat dari nilai Fhitung $>$ Ftabel dan sig $<0,05 \quad(0,000)$. Kemudian kontribusi pengaruh simultan kepemimpinan dan disiplin sebesar $56,9 \%$ sedangkan sisanya sebesar $43,1 \%$ dipengaruhi faktor lain. Dengan demikian hipotesis ketiga yang diajukan bahwa terdapat berpengaruh signifikan antara kepemimpinan dan disiplin kerja terhadap produktivitas kerja diterima.

\section{KESIMPULAN DAN SARAN}

\section{A. Kesimpulan}

1. Hasil uji hipotesis dengan menggunakan analisis regresi linear berganda menunjukkan bahwa variabel gaya kepemimpinan (X1) secara parsial berpengaruh positif dan signifikan terhadap produktivitas kerja PT. Pelindo IV (Persero) Makassar.

2. Hasil uji hipotesis dengan menggunakan analisis regresi linear berganda menunjukkan bahwa variabel gaya disiplin kerja (X2) secara parsial berpengaruh positif dan signifikan terhadap produktivitas kerja PT. Pelindo IV (Persero) Makassar.

3. Hasil uji hipotesis dengan menggunakan analisis regresi linear berganda menunjukkan bahwa variable gaya kepemimpinan (X1) dan disiplin kerja (X2) secara simultan berpengaruh positif dan signifikan terhadap produktivitas kerja PT. Pelindo IV (Persero) Makassar.

\section{B. Saran}

Berdasarkan pembahasan dan hasil penelitian, maka penulis memberikan beberapa saran sebagai berikut:

1. Perusahaan dalam hal ini PT. Pelindo IV (persero) Makassar lebih berupa lagi lebih mengayomi dan dekat dengan bawahan dan menerapkan gaya kepemimpinan sesuai dengan budaya perusahaan yang telah ada.

2. Masih rendahnya tingkat disiplin karyawan menjadi perhatian serius bagi PT. Pelindo IV (persero) Makassar agar mencariakan solusi pola pelatihan disiplin berdasarkan regulasi yang telah ditetapkan

\section{DAFTAR PUSTAKA}

Ahmad, T. S., \& Thamrin, A. M. R. (2021). Pengaruh Gaya Kepemimpinan Terhadap Kinerja Karyawan Pada PT. 
Pelindo IV (Persero) Cabang Makassar. Movere Journal, 3(1), 1-16.

Alam, S., \& Hasbiyadi, H. (2021). Kepemimpinan dan Praktek Total Quality Management terhadap Kinerja Perbankan Syariah di Kota Makassar. Jurnal Administrasi Bisnis (JAB), 11(1), 37-42.

Asbari, M., Purwanto, A., \& Santoso, P. B. (2020). Pengaruh Iklim Organisasi dan Kepemimpinan Transformasional Terhadap Produktivitas Kerja Inovatif Pada Industri Manufaktur di Pati Jawa Tengah. Jurnal Produktivitas: Jurnal Fakultas Ekonomi Universitas Muhammadiyah Pontianak, 7(1).

Halim, A. (2020). Pengaruh Gaya Kepemimpinan Terhadap Kinerja Pegawai Pada Dinas Pendidikan Dan Kebudayaan Kota Makassar. Publik: Jurnal Manajemen Sumber Daya Manusia, Administrasi dan Pelayanan Publik, 7(2), 92104.

Hasibuan, H Malayu. (2012). Manajemen Sumber Daya Manusia. Edisi revisi, cetakan ke 3. Penerbit PT. Bumi Aksara. Jakarta.

Huang, Tung Chun. (1997). "The Effect of Participative Management on Organizational Performance: The Case of Taiwan", The International Journal of Human Resource Management, Vol. 8 (5), pp 677-687.

Jannah, A. S. R., \& Jumady, E. (2020). Efek Pemberian Insentif Dan Komitmen Dalam
Upaya Peningkatan

Produktivitas Kerja Karyawan Pt Gelael Supermarket Makassar. Al-KALAM Jurnal Komunikasi, Bisnis Dan Manajemen, 7(2), 83-94.

Jumady, E. (2020). Implementation of Total Quality Management and Leadership on Islamic Banking Financial Performance. ATESTASI: Jurnal Ilmiah Akuntansi, 3(2), 163-170.

Jumady, E. (2020). Peran Moderasi Disiplin Kerja Pada Pengaruh Kepemimpinan Terhadap Produktivitas Kerja Karyawan Perbankan Syariah Di Makassar. Islamic Banking: Jurnal Pemikiran Dan Pengembangan Perbankan Syariah, 5(2), 1-20.

Jumady, E. (2021). Engagement or Sustainability: Managerial Performance. Jurnal Manajemen Bisnis, 8(1), 67-73. Mangkuprawira, Sjafri dan Aida Vitayala Hubeis. (2007). Manajemen Mutu Sumber Daya Manusia. Cetakan Pertama. Ghalia Indonesia. Bogor.

Mappamiring, .. (2020). Motivasi dan

Kepemimpinan terhadap Kepuasan Kerja Karyawan PT. Telelekomunikasi Indonesia (Persero) Tbk Pusat Makassar. Jurnal Administrasi Bisnis (JAB), $\quad$ 10(2), $\quad$ 86-92. doi:https://doi.org/10.35797/ja b.10.2.2020.31286.86-92

Nurlina, N., \& Jumady, E. (2021). The Role of Motivation as Mediating Relationship Between Incentives and Employee Performance. Jurnal Economic Resource, 3(2), 4451. 
Posuma, C. (2013). Kompetensi, Kompensasi, Dan Kepemimpinan Pengaruhnya Terhadap Kinerja Karyawan Pada Rumah Sakit Ratumbuysang Manado. Jurnal Riset Ekonomi, Manajemen, Bisnis Dan Akuntansi, 1(4), 646-656.

Rapanna, P., \& Jumady, E. (2020). The Impact of Corona Virus Outbreak Regarding the LargeScale Social Restriction Policy on Economic Attitudes in Makassar. Int'l J. Soc. Sci. Stud., 8, 83 .

Sedarmayanti. (2009). Sumber Daya Manusia dan Produktivitas Kerja. Bandung:Mandar Maju. Lembaga Penerbit Fakultas Ekonomi UI. Jakarta.

Shelviana, S. (2015). Hubungan disiplin kerja dengan kinerja Pegawai Negeri Sipil (PNS) di Kecamatan Samarinda Ulu Kota Samarinda. E-Journal Ilmu Administrasi Negara, 3(1).

Siswadi, Y. (2017). Pengaruh Pelatihan Dan Disiplin Terhadap Produktivitas Kerja Karyawan Padapt. Jasa Marga
Cabang (Belmera) Medan. Jurnal Ilmiah Manajemen dan Bisnis, 17(1).

Sunarsi, D. (2014). Pengaruh Gaya Kepemimpinan, Motivasi dan Disiplin Kerja Terhadap Kinerja Pendidik (Doctoral dissertation, Universitas Pamulang).

Suryani, P., Cahyono, Y., \& Utami, B. D. (2020). Pengaruh Motivasi Dan Gaya Kepemimpinan Terhadap Produktivitas Kerja Karyawan Produksi di PT Tuntex Garment Indonesia. Journal of Industrial Engineering \& Management Research, 1(1), 70-82.

Sutrisno, S., \& Sunarsi, D. (2019). The Effect of Work Motivation and Discipline on Employee Productivity at PT. Anugerah Agung in Jakarta. Jurnal Ad'ministrare, 6(2), 187-196.

Widodo, T. (2010). Pengaruh Lingkungan Kerja, Budaya Organisasi, Kepemimpinan Terhadap Kinerja (Studi pada Pegawai Kecamatan Sidorejo Kota Salatiga). Jurnal Among Makarti, 3(5), 14-35. 